\title{
Theoretical Gas Phase Study of the Gauche and Trans Conformers of 1-Bromo-2-Chloroethane and Solvent Effects
}

\author{
Ponnadurai Ramasami \\ Faculty of Science, Department of Chemistry, Univeristy of Mauritius, Réduit, Republic of \\ Mauritius \\ p.ramasami@uom.ac.mu \\ www.pages.intnet.mu/ramasami/
}

\begin{abstract}
This is a systematic gas phase study of the gauche and trans conformers of 1-bromo-2-chloroethane. The methods used are second order Møller-Plesset theory (MP2) and density functional theory (DFT). The basis set used is $6-311++\mathrm{G}(\mathrm{d}, \mathrm{p})$ for all atoms. The functional used for DFT method is B3LYP. G2/MP2 and CCSD(T) calculations have also been carried out using MP2 optimised structure. The results indicate that there is more preference for the trans conformer. The energy difference between the trans and gauche conformers $\left(\Delta \mathrm{E}_{\mathrm{tg}}\right)$ and related rotational thermodynamics are reported. The MP2/6$311++\mathrm{G}(\mathrm{d}, \mathrm{p})$ energy difference $\left(\Delta \mathrm{E}_{\mathrm{tg}}\right)$ for 1-bromo-2-chloroethane is 7.08 $\mathrm{kJ} / \mathrm{mol}$. The conformers of 1-bromo-2-chloroethane have also been subjected to vibrational analysis. This study has also been extended to investigate solvent effects using the Self-Consistent Reaction Field methods. The structures of the conformers are not much affected by the solvents but the energy difference $\left(\Delta \mathrm{E}_{\mathrm{tg}}\right)$ decreases with increasing polarity of the solvent. The results from the different theoretical methods are in good agreement.
\end{abstract}

\section{Introduction}

100 years ago, Bischoff found that $\mathrm{C}-\mathrm{C}$ single bond in ethane is not completely free [1]. Due to the hindered internal rotation, 1,2-disubstituted ethanes are the simplest molecules showing conformational isomerism thus leading to the gauche and trans conformers. It is generally found that the trans conformer is more stable than the gauche form and this is due to steric hindrance in the gauche conformation [2]. Theoretical calculations of the energy difference between the trans and gauche conformers $\left(\Delta \mathrm{E}_{\mathrm{tg}}\right)$ have been actively pursued for over 40 years, as they are important parameters to the conformational analysis of molecules [3].

In previous communications, energy differences $\left(\Delta \mathrm{E}_{\mathrm{tg}}\right)$ have been calculated for 1,2-dihaloethanes $\left(\mathrm{XCH}_{2} \mathrm{CH}_{2} \mathrm{X}, \mathrm{X}=\mathrm{F}, \mathrm{Cl}, \mathrm{Br}\right.$ and I) [4] and for 1-fluoro-2-haloethanes $\left(\mathrm{FCH}_{2} \mathrm{CH}_{2} \mathrm{X}, \mathrm{X}=\mathrm{Cl}, \mathrm{Br}\right.$ and I) [5] in the gas phase. These studies indicate that except for 1,2-difluoroethane, the trans conformer is more stable that the gauche conformer. The energy difference $\left(\Delta \mathrm{E}_{\mathrm{tg}}\right)$ increases with the size of the halogen. The atypical 
behaviour of 1,2-difluoroethane has been associated with the gauche effect [6-10] but the latter is not observed for the 1-fluoro-2-haloethanes. Solvent effects have also been explored for 1,2-dichloroethane and 1,2-dibromoethane [11]. The study indicates that an increase in the solvent polarity decreases the energy difference $\left(\Delta \mathrm{E}_{\mathrm{tg}}\right)$. It is worth to point out at this stage that literature involving theoretical studies is limited with respect to solvent effects [11,12] although polarity of the solvent is known to affect conformational equilibrium [13].

As part of a continuing series of studies on internal rotation [4-5,11], 1-bromo-2chloroethane has been the target of this work. 1-Bromo-2-chloroethane, being a 1,2disubstituted ethane, can exist as the gauche $\left(C_{l}\right.$ symmetry) and trans $\left(\mathrm{C}_{s}\right.$ symmetry $)$ conformers as illustrated in Figure 1.

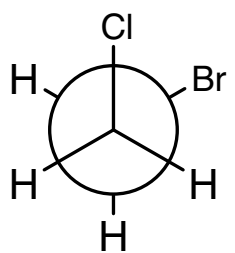

Gauche conformer ( $C_{1}$ symmetry)

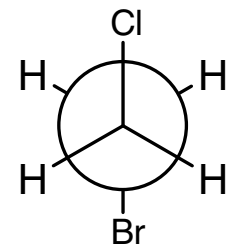

Trans conformer $\left(\mathrm{C}_{s}\right.$ symmetry $)$

Fig. 1. Gauche and Trans conformers of 1-bromo-2-chloroethane

These gauche and trans conformers of 1-bromo-2-chloroethane have been studied with a view to obtain (i) the optimised structural parameters, (ii) the energy difference $\left(\Delta \mathrm{E}_{\mathrm{tg}}\right)$ and (iii) related thermodynamics properties for torsional rotation. Apart from energy calculations, the conformers of 1-bromo-2-chloroethane have also been subjected to vibrational analysis. Solvent effects, using Self-Consistent Reaction Field (SCRF) methods [14], have also been explored with the dielectric constant of the solvent varying from 5 to 40 . The results of the present investigation are reported herein and to the best of our knowledge there has not been such a type of investigation.

\section{Calculations}

All the calculations have been carried out using Gaussian 03W [15] program suite and Gauss View 3.0 [16] has been used for visualising the molecules. The calculations have been carried out using second order Møller-Plesset perturbation theory (MP2) and density functional theory (DFT). The basis set used is $6-311++G(d, p)$ for all atoms. The functional used for DFT method is B3LYP. A conformer has first been optimised and the optimised structure has then been used for frequency calculation using the same method and basis set involved for optimisation. G2/MP2 and 
$\operatorname{CCSD}(\mathrm{T})$ calculations have also been carried out using MP2/6-311++G(d,p) optimised structure. For all the converged structures, frequencies calculations have also been carried out in order to ensure that this conformation corresponds to a minimum. The SCRF methods used are Isodensity Model (SCRF=IPCM) [14] and Self-Consistent Isodensity Model (SCRF=SCIPCM) [14]. MP2/6-311++G(d,p) gas phase optimised structures have been used for the single point calculations for the Isodensity Model and B3LYP/6-311++G(d,p) full geometry optimisation calculations have been carried for the Self-Consistent Isodensity Model.

\section{Results and Discussion}

The optimised structural parameters, which are of interest for the two conformers of 1-bromo-2-chloroethane, are summarised in Table 1. Analysis of Table 1 allows some conclusions to be made. Firstly, for both conformers the predicted $\mathrm{C}-\mathrm{Cl}$ and $\mathrm{C}-\mathrm{Br}$ bond lengths are longer from B3LYP calculation although the $\mathrm{C}-\mathrm{C}$ and $\mathrm{C}-\mathrm{H}$ bond lengths are nearly same. Secondly the bond angles $\mathrm{CCCl}$ and $\mathrm{CCBr}$ are larger for the gauche conformer than the trans conformer. This can be explained in terms of greater amount of steric repulsion between the halogen atoms in the gauche conformation. Further these bond angles are larger from B3LYP calculation. However, these bond angles are nearly same for the trans conformer for both methods. Thirdly, the torsional angle $\mathrm{ClCCBr}$ for the gauche conformer is larger from B3LYP calculation. Lastly the moments of inertia are generally greater from MP2 calculation with $\mathrm{I}_{\mathrm{A}}>\mathrm{I}_{\mathrm{B}} \approx \mathrm{I}_{\mathrm{C}}$.

Table 1. Optimised structural parameters for the gauche and trans conformers of 1-bromo-2chloroethane using 6-311++G(d,p) as the basis set

\begin{tabular}{ccccc}
\hline Parameter & \multicolumn{3}{c}{ B3LYP } & MP2 \\
\hline $\mathrm{r}(\mathrm{C}-\mathrm{Cl}) / \AA$ & Gauche & Trans & Gauche & Trans \\
$\mathrm{r}(\mathrm{C}-\mathrm{C}) / \AA$ & 1.809 & 1.821 & 1.776 & 1.783 \\
$\mathrm{r}(\mathrm{C}-\mathrm{Br}) / \AA$ & 1.511 & 1.512 & 1.512 & 1.512 \\
$\mathrm{r}(\mathrm{C}-\mathrm{H}) / \AA$ & 1.973 & 1.980 & 1.937 & 1.941 \\
$\angle(\mathrm{CCCl}) / \AA$ & 1.090 & 1.087 & 1.090 & 1.089 \\
$\angle(\mathrm{CCBr}) /{ }^{\circ}$ & 113.2 & 109.0 & 112.3 & 109.0 \\
$\tau(\mathrm{ClCCBr}) /{ }^{\circ}$ & 113.3 & 109.2 & 112.6 & 109.5 \\
Dipole $\mathrm{moment} / \mathrm{D}$ & 70.4 & 180.0 & 68.0 & 180.0 \\
$\mathrm{I}_{\mathrm{A}} / \mathrm{GHz}$ & 2.826 & 0.013 & 3.067 & 0.015 \\
$\mathrm{I}_{\mathrm{B}} / \mathrm{GHz}$ & 8.870 & 28.689 & 8.862 & 28.909 \\
$\mathrm{I}_{\mathrm{C}} / \mathrm{GHz}$ & 1.427 & 0.961 & 1.509 & 0.991 \\
\hline
\end{tabular}


The energies of the gauche and trans conformers of the 1-bromo-2-chloroethane are given in Table 2. These energies have been obtained after full geometry optimisation which has been verified by frequency calculation. G2/MP2 and CCSD(T) energies are also given in Table 2. As part of G2/MP2 and CCSD(T) calculations, MP2/6$311+\mathrm{G}(3 \mathrm{df}, 2 \mathrm{p})$ and MP3/6-311++G(d,p) energies are included in Table 2. The energy difference $\left(\Delta \mathrm{E}_{\mathrm{tg}}\right)$ and related rotational thermodynamic parameters are also summarised in Table 2. A glance at Table 2 clearly shows that the trans conformer is more stable. The energy difference $\left(\Delta \mathrm{E}_{\mathrm{tg}}\right)$ predicted using B3LYP method is greater than MP2 method for the same basis set. The free energy difference $\left(\Delta \mathrm{G}_{\mathrm{tg}}\right)$ can be used to estimate the relative percentage of the trans and gauche conformers. It is found that at $298 \mathrm{~K}$, the percentage of the trans conformer is generally greater than $90 \%$. At this stage, it is interesting to compare the energy difference $\left(\Delta \mathrm{E}_{\mathrm{tg}}\right)$ of the unsymmetrical 1-bromo-2-chloroethane with the symmetrical 1,2-dichloroethane and 1,2dibromoethane. The MP2/6-311++G(d,p) values for these compounds are 6.08 and $8.79 \mathrm{~kJ} / \mathrm{mol}$ respectively [4].

Table 2. Calculated energies and rotational thermodynamic parameters for the conformers of 1-bromo-2-chloroethane

\begin{tabular}{|c|c|c|c|c|c|c|}
\hline Method & $\begin{array}{c}\text { Gauche } \\
\text { (Hartrees) }\end{array}$ & $\begin{array}{c}\text { Trans } \\
\text { (Hartrees) }\end{array}$ & $\begin{array}{c}\Delta \mathrm{E}_{\mathrm{tg}} \\
(\mathrm{kJ} / \mathrm{mol})\end{array}$ & $\begin{array}{c}\Delta \mathrm{H}_{\mathrm{tg}} \\
(0 \mathrm{~K}) \\
(\mathrm{kJ} / \mathrm{mol})\end{array}$ & $\begin{array}{c}\Delta \mathrm{H}_{\mathrm{tg}} \\
(298 \mathrm{~K}) \\
(\mathrm{kJ} / \mathrm{mol})\end{array}$ & $\begin{array}{c}\Delta \mathrm{G}_{\mathrm{tg}} \\
(298 \mathrm{~K}) \\
(\mathrm{kJ} / \mathrm{mol})\end{array}$ \\
\hline B3LYP/6-311++G(d,p) & -3113.0202578 & -3113.0234642 & 8.42 & & 7.65 & 8.01 \\
\hline $\mathrm{MP} 2 / 6-311++\mathrm{G}(\mathrm{d}, \mathrm{p})$ & -3111.0127999 & -3111.0154953 & 7.08 & & 6.45 & 6.86 \\
\hline $\mathrm{MP} 2 / 6-311+\mathrm{G}(3 \mathrm{df}, 2 \mathrm{p})$ & -3110.6755106 & -3110.6778141 & 6.05 & & & \\
\hline G2/MP2 & -3110.7491862 & -3110.7515898 & & 6.31 & 5.88 & 6.26 \\
\hline $\mathrm{MP} 3 / 6-311++\mathrm{G}(\mathrm{d}, \mathrm{p})$ & -3110.5697388 & -3110.5725913 & 7.49 & & & \\
\hline $\operatorname{CCSD}(\mathrm{T}) / 6-311++\mathrm{G}(\mathrm{d}, \mathrm{p})$ & -3110.5944679 & -3110.5972661 & 7.35 & & & \\
\hline
\end{tabular}

The gauche and trans conformers of 1-bromo-2-chloroethane have also been subjected to vibrational analysis. The calculated frequencies are reported in Table 3 and the simulated spectra are illustrated in Figure 2. The 18 modes of vibrations account for the irreducible representations $\Gamma_{\mathrm{v}}=18 \mathrm{~A}$ of the $C_{1}$ point group of the gauche conformer and $\Gamma_{\mathrm{v}}=11 \mathrm{~A}^{\prime}+7 \mathrm{~A}^{\prime \prime}$ of the $C_{\mathrm{s}}$ point group of the trans conformer. All the 18 fundamentals of the gauche and trans conformers have been assigned appropriately. The values indicate that predictions with MP2 level of theory are systematically larger than B3LYP level of theory. Since steric interaction between the atoms is more in the gauche than trans conformer, the $\mathrm{CCCl}$ and $\mathrm{CCBr}$ bending modes have higher frequencies in the gauche conformation than the trans conformation. The bending vibrational modes of the $\mathrm{CH}_{2}$ group are in the order scissoring > wagging $>$ twisting $>$ rocking. The bending mode of the $\mathrm{CH}_{2}$ group attached to bromine atom is at a lower frequency compared to $\mathrm{CH}_{2}$ group attached to chlorine atom. This can be explained on the basis of reduced mass for $\mathrm{CH}_{2}$ group when attached to bromine atom. However the stretching vibrational modes of the $\mathrm{CH}_{2}$ group bonded to the halogen atoms are reversed in terms of frequency. The calculated frequentcies for 1-bromo-2-chloroethane are in agreement with literature values obtained experimentally [17]. 
Table 3. Calculated frequencies $\left(\mathrm{cm}^{-1}\right)$ of the conformers of 1-bromo-2-chloroethane and their assignments

\begin{tabular}{|c|c|c|c|c|c|c|c|}
\hline \multicolumn{4}{|c|}{ Gauche } & \multicolumn{4}{|c|}{ Trans } \\
\hline B3LYP & MP2 & $\begin{array}{c}\text { Literature } \\
{[17]}\end{array}$ & Assignments & B3LYP & MP2 & $\begin{array}{c}\text { Literature } \\
{[17]}\end{array}$ & Assignments \\
\hline $\begin{array}{l}3158.9 \\
(1.4)\end{array}$ & $\begin{array}{l}3206.7 \\
(1.7)\end{array}$ & 3010 & $\mathrm{CH}_{2}$ a str & $\begin{array}{l}3185.5 \\
(0.9)\end{array}$ & $\begin{array}{l}3229.5 \\
(1.1)\end{array}$ & 3010 & $\mathrm{CH}_{2}$ a str \\
\hline $\begin{array}{l}3138.2 \\
(1.2)\end{array}$ & $\begin{array}{l}3190.4 \\
(1.4)\end{array}$ & 3010 & $\mathrm{CH}_{2}$ a str & $\begin{array}{l}3159.9 \\
(0.4)\end{array}$ & $\begin{array}{l}3207.5 \\
(0.4)\end{array}$ & 3010 & $\mathrm{CH}_{2}$ a str \\
\hline $\begin{array}{l}3090.1 \\
(12.3)\end{array}$ & $\begin{array}{l}3131.8 \\
(13.9)\end{array}$ & 2960 & $\mathrm{CH}_{2}$ s str & $\begin{array}{l}1292.6 \\
(0.02)\end{array}$ & $\begin{array}{l}1314.6 \\
(0.02)\end{array}$ & 1259 & $\mathrm{CH}_{2}$ twist \\
\hline $\begin{array}{l}3071.8 \\
(8.9)\end{array}$ & $\begin{array}{l}3120.2 \\
(9.6)\end{array}$ & 2960 & $\mathrm{CH}_{2}$ s str & $\begin{array}{l}11219.3 \\
(2.6)\end{array}$ & $\begin{array}{l}1158.3 \\
(3.1)\end{array}$ & 1111 & $\mathrm{CH}_{2}$ twist \\
\hline $\begin{array}{l}1469.1 \\
(3.0)\end{array}$ & $\begin{array}{l}1481.0 \\
(1.0)\end{array}$ & 1428 & $\mathrm{CH}_{2}$ scis & $\begin{array}{l}975.6 \\
(0.3)\end{array}$ & $\begin{array}{l}1011.3 \\
(0.5)\end{array}$ & 961 & $\mathrm{CH}_{2}$ rock \\
\hline $\begin{array}{l}1461.7 \\
(10.8)\end{array}$ & $\begin{array}{l}1471.7 \\
(10.6)\end{array}$ & 1428 & $\mathrm{CH}_{2}$ scis & $\begin{array}{l}771.1 \\
(3.3)\end{array}$ & $\begin{array}{l}785.0 \\
(2.2)\end{array}$ & 763 & $\mathrm{CH}_{2}$ rock \\
\hline $\begin{array}{l}1338.6 \\
(25.4)\end{array}$ & $\begin{array}{l}1382.1 \\
(24.3)\end{array}$ & 1299 & $\mathrm{CH}_{2}$ wag & $\begin{array}{l}109.2 \\
(6.0)\end{array}$ & $\begin{array}{l}119.0 \\
(5.1)\end{array}$ & 123 & Torsion \\
\hline $\begin{array}{l}1296.5 \\
(57.3)\end{array}$ & $\begin{array}{l}1337.9 \\
(45.2)\end{array}$ & 1260 & $\mathrm{CH}_{2}$ wag & $\begin{array}{l}3113.3 \\
(7.7)\end{array}$ & $\begin{array}{l}3151.1 \\
(10.4)\end{array}$ & 2960 & $\mathrm{CH}_{2} \mathrm{~s}$ str \\
\hline $\begin{array}{l}1211.4 \\
(3.2)\end{array}$ & $\begin{array}{l}1244.7 \\
(3.0)\end{array}$ & 1190 & $\mathrm{CH}_{2}$ twist & $\begin{array}{l}3102.3 \\
(1.9)\end{array}$ & $\begin{array}{l}3142.4 \\
(1.5)\end{array}$ & 2960 & $\mathrm{CH}_{2}$ s str \\
\hline $\begin{array}{l}1146.6 \\
(1.5)\end{array}$ & $\begin{array}{l}1179.2 \\
(2.0)\end{array}$ & 1127 & $\mathrm{CH}_{2}$ twist & $\begin{array}{l}1490.9 \\
(1.5)\end{array}$ & $\begin{array}{l}1499.7 \\
(0.04)\end{array}$ & 1446 & $\mathrm{CH}_{2}$ scis \\
\hline $\begin{array}{l}1038.2 \\
(1.8)\end{array}$ & $\begin{array}{l}1077.7 \\
(1.3)\end{array}$ & 1025 & CC str & $\begin{array}{l}1486.8 \\
(5.6)\end{array}$ & $\begin{array}{l}1493.9 \\
(5.1)\end{array}$ & 1444 & $\mathrm{CH}_{2}$ scis \\
\hline $\begin{array}{l}928.7 \\
(9.1)\end{array}$ & $\begin{array}{l}968.6 \\
(6.9)\end{array}$ & 923 & $\mathrm{CH}_{2}$ rock & $\begin{array}{l}1320.9 \\
(2.7)\end{array}$ & $\begin{array}{l}1372.4 \\
(2.9)\end{array}$ & 1284 & $\mathrm{CH}_{2}$ wag \\
\hline $\begin{array}{l}868.5 \\
(23.1)\end{array}$ & $\begin{array}{l}898.7 \\
(18.5)\end{array}$ & 856 & $\mathrm{CH}_{2}$ rock & $\begin{array}{l}1237.0 \\
(49.6)\end{array}$ & $\begin{array}{l}1272.9 \\
(49.1)\end{array}$ & 1203 & $\mathrm{CH}_{2}$ wag \\
\hline $\begin{array}{l}658.4 \\
(26.0)\end{array}$ & $\begin{array}{l}724.2 \\
(13.8)\end{array}$ & 664 & $\mathrm{CCl}$ str & $\begin{array}{l}1060.7 \\
(1.0)\end{array}$ & $\begin{array}{l}1100.8 \\
(1.2)\end{array}$ & 1052 & $\mathrm{CC}$ str \\
\hline $\begin{array}{l}555.0 \\
(13.9)\end{array}$ & $\begin{array}{l}610.6 \\
(8.7)\end{array}$ & 571 & $\mathrm{CBr}$ str & $\begin{array}{l}716.3 \\
(30.4)\end{array}$ & $\begin{array}{l}803.3 \\
(24.5)\end{array}$ & 726 & $\mathrm{CCl}$ str \\
\hline $\begin{array}{l}382.0 \\
(8.7)\end{array}$ & $\begin{array}{l}397.1 \\
(5.5)\end{array}$ & 385 & $\mathrm{CCCl}$ deform & $\begin{array}{l}616.2 \\
(70.1)\end{array}$ & $\begin{array}{l}688.6 \\
(40.6)\end{array}$ & 630 & $\mathrm{CBr}$ str \\
\hline $\begin{array}{l}241.6 \\
(1.4)\end{array}$ & $\begin{array}{l}251.0 \\
(0.9)\end{array}$ & 251 & $\mathrm{CCBr}$ deform & $\begin{array}{l}242.2 \\
(0.9)\end{array}$ & $\begin{array}{l}259.1 \\
(0.7)\end{array}$ & 251 & $\mathrm{CCCl}$ deform \\
\hline $\begin{array}{l}94.1 \\
(0.6)\end{array}$ & $\begin{array}{l}106.6 \\
(0.5) \\
\end{array}$ & 107 & Torsion & $\begin{array}{l}191.1 \\
(7.8)\end{array}$ & $\begin{array}{l}201.0 \\
(6.4) \\
\end{array}$ & 202 & $\mathrm{CCBr}$ deform \\
\hline
\end{tabular}

-Values in bracket are infrared intensities in $(\mathrm{km} / \mathrm{mol})$

-For the trans conformer, first 11 frequencies are of $\mathrm{A}^{\prime}$ symmetry and last 8 frequencies are of $\mathrm{A}^{\prime \prime}$ symmetry

-For the gauche conformer, all 18 frequencies are of A symmetry

This study has also been extended to study solvent effects. The structures of the conformers are not much affected by the polarity of the polarity of the solvents. The effects of solvent on the energy of the gauche and trans conformers and energy difference $\left(\Delta \mathrm{E}_{\mathrm{tg}}\right)$ are summarised in Table 4 and illustrated in Figure 3. It can be found that solvent effects are small but they can be calculated and an increase in the polarity of 
the solvent decreases the energy difference $\left(\Delta \mathrm{E}_{\mathrm{tg}}\right)$. However in the polar solvents, the decrease in the energy of the more polar gauche conformer is larger than the trans conformer.

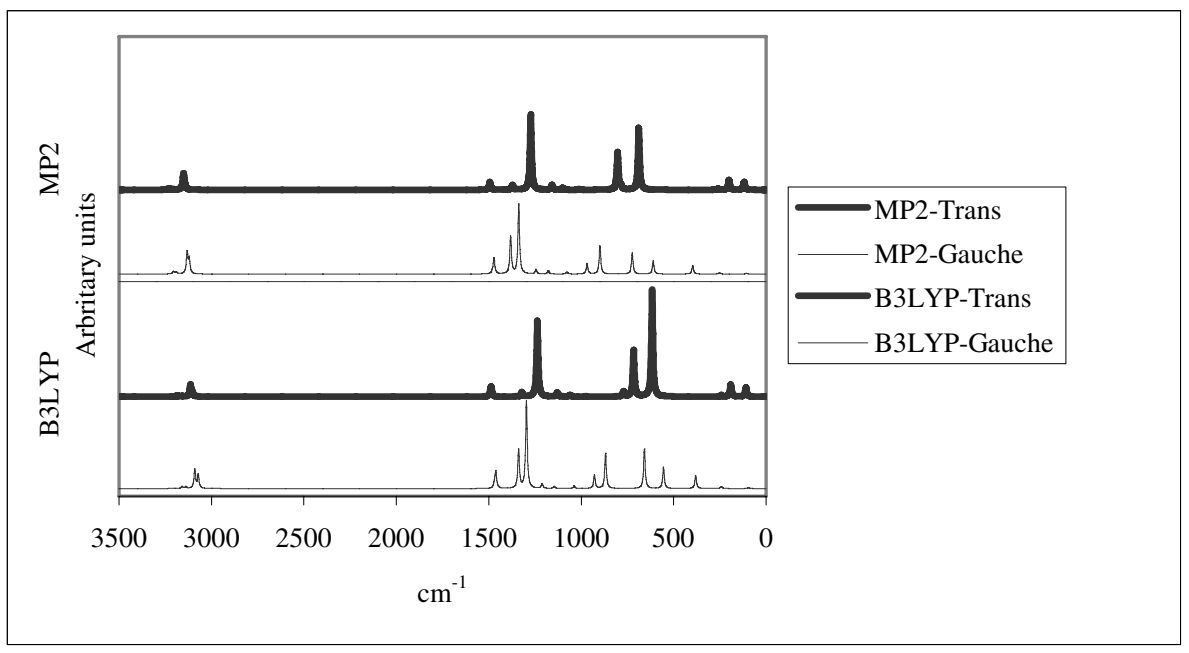

Fig. 2. Simulated spectra of the gauche and trans conformers of 1-bromo-2-chloroethane

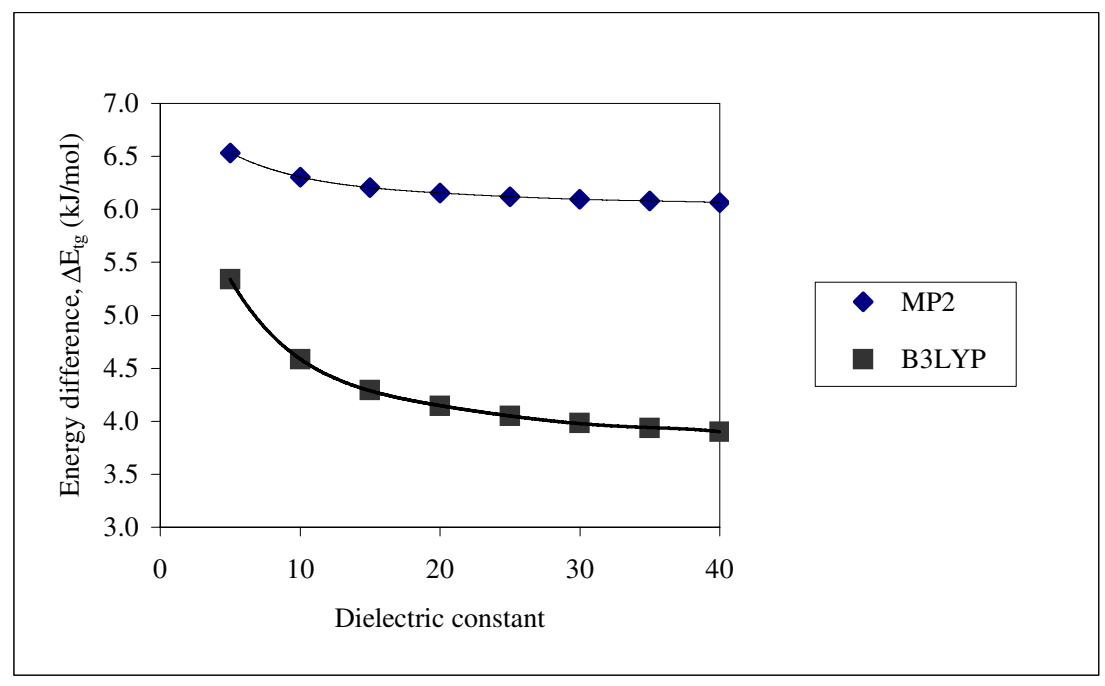

Fig. 3. Energy difference $\left(\Delta \mathrm{E}_{\mathrm{tg}}\right)$ for 1-bromo-2-chloroethane in solvents with different dielectric constants 
Table 4. Energy and energy difference $\left(\Delta \mathrm{E}_{\mathrm{tg}}\right)$ for the conformers of 1-bromo-2-chloroethane in solvents with different dielectric constants

\begin{tabular}{lcclcll}
\hline \multicolumn{5}{c}{ MP2 } & \multicolumn{3}{c}{ B3LYP } \\
\hline$\varepsilon$ & $\begin{array}{l}\text { Gauche } \\
\text { (Hartrees) }\end{array}$ & $\begin{array}{l}\text { Trans } \\
\text { (Hartrees) }\end{array}$ & $\begin{array}{l}\Delta \mathrm{E}_{\mathrm{tg}} \\
(\mathrm{kJ} / \mathrm{mol})\end{array}$ & $\begin{array}{l}\text { Gauche } \\
(\text { Hartrees })\end{array}$ & $\begin{array}{l}\text { Trans } \\
(\text { Hartrees })\end{array}$ & $\begin{array}{l}\Delta \mathrm{E}_{\mathrm{tg}} \\
(\mathrm{kJ} / \mathrm{mol})\end{array}$ \\
\hline 5 & -3110.5351096 & -3110.5326210 & 6.53 & -3113.0262618 & -3113.0242279 & 5.34 \\
10 & -3110.5356523 & -3110.5332507 & 6.31 & -3113.0268009 & -3113.0250547 & 4.58 \\
15 & -3110.5358531 & -3110.5334889 & 6.21 & -3113.0269959 & -3113.0253597 & 4.30 \\
20 & -3110.5359575 & -3110.5336138 & 6.15 & -3113.0270967 & -3113.0255187 & 4.14 \\
25 & -3110.5360216 & -3110.5336906 & 6.12 & -3113.0271582 & -3113.0256163 & 4.05 \\
30 & -3110.5360649 & -3110.5337428 & 6.10 & -3113.0271996 & -3113.0256822 & 3.98 \\
35 & -3110.5360961 & -3110.5337807 & 6.08 & -3113.0272295 & -3113.0257298 & 3.94 \\
40 & -3110.5361197 & -3110.5338094 & 6.07 & -3113.0272520 & -3113.0257657 & 3.90 \\
\hline
\end{tabular}

$\varepsilon$ : Dielectric constant.

\section{Conclusions}

This theoretical study has lead to the determination of the optimised structural parameters, the energy difference $\left(\Delta \mathrm{E}_{\mathrm{tg}}\right)$ and related thermodynamics parameters for 1-bromo-2-chloroethane. The results indicate that there is a preference for the trans conformer both in the gaseous and solution phases. The calculated frequencies of the conformers are in agreement with literature values. The energy difference $\left(\Delta \mathrm{E}_{\mathrm{tg}}\right) \mathrm{de}$ creases as the solvent becomes more polar. The results of this study may be used as a set of reference for the conformers of 1-bromo-2-chloroethane.

\section{Acknowledgements}

The author is grateful to anonymous reviewers for their comments to improve the manuscript. The author acknowledges the facilities from the University of Mauritius.

\section{References}

1. Orville-Thomas W.J.: Internal Rotation in Molecules. Wiley, New York, 1974

2. Dixon D.A., Matsuzawa N., Walker S.C.: Conformational Analysis of 1,2-Dihaloethanes: A Comparison of Theoretical Methods. J. Phys. Chem. 96 (1992) 10740-10746

3. Radom L., Baker J., Gill P.M.W., Nobes R.H., Riggs N.V.: A Theoretical Approach to Molecular Conformational Analysis. J. Mol. Struc. 126 (1985) 271-290

4. Ramasami P.: Gauche and Trans Conformers of 1,2-Dihaloethanes: A Study by Ab initio and Density Functional Theory Methods. Lecture Series on Computer and Computational Sciences. Vol. 1, Brill Academic Publishers, The Netherlands (2005) 732-734

5. Ramasami P.: Gas Phase Study of the Gauche and Trans Conformers of 1-Fluoro-2Haloethanes $\mathrm{CH}_{2} \mathrm{~F}-\mathrm{CH}_{2} \mathrm{X}(\mathrm{X}=\mathrm{Cl}, \mathrm{Br}, \mathrm{I})$ by $\mathrm{Ab}$ initio and Density Functional Methods: $\mathrm{Ab}$ sence of Gauche Effect. Lecture Notes in Computer Science. Vol. 3993, Springer, (2006) $153-160$ 
6. Tavasli M., O’Hagan D., Pearson C. Petty M.C.: The Fluorine Gauche Effect. Langmuir Isothems Reprot the Relative Conformational Stability of (+/-)-Erythro- and (+/-)-Threo9,10-Difluorostearic acids. Chem. Commun. 7 (2002) 1226-1227

7. Briggs C.R., Allen M.J., O'Hagan D., Tozer D.J., Slawin A.M., Geota A.E., Howard J.A.: The Observation of a Large Gauche Preference when 2-Fluoroethylmanine and 2Fluoroethanol Become Protonated. Org. Biomol. Chem. 2 (2004) 732-740

8. Banks J.W., Batsanov A.S., Howard J.A.K., O’Hagan D., Rzepa H.S., Martin-Santamaria S.: The Preferred Conformation of $\alpha$-Fluoroamides. J. Chem. Soc., Perkin Trans. 2. 8 (1999) 2409-2411

9. Wiberg K.B., Murcko M. A., Laidig E.K., MacDougall P. J.: Origin of the "Gauche Effect" in Substituted Ethanes and Ethenes. The Gauche Effect. J. Phys. Chem. 96 (1992) 6956-6959 and references therein

10. Harris W.C., Holtzclaw J.R., Kalasinsky V.F.: Vibrational Spectra and Structure of 1,2Difluoroethane: Gauche-Trans Conformers. J. Chem. Phys. 67 (1977) 3330-3338

11. Sreeruttun R. K., Ramasami P.: Conformational Behaviour of 1,2-Dichloroethane and 1,2Dibromoethane: 1H-NMR, IR, Refractive index and Theoretical Studies. Physics and Chemistry of Liquids. 44 (2006) 315-328

12. Wiberg K.B., Keith T.A., Frisch M.J., Murcko M.: Solvent Effects on 1,2-Dihaloethane Gauche/Trans Ratios. J. Phys. Chem. 99 (1995) 9072-9079

13. McClain B.L., Ben-Amotz D.: Global Quantitation of Solvent Effects on the Isomerization Thermodynamics of 1,2-Dichloroethane and trans-1,2-Dichlorocyclohexane. J. Phys. Chem. B 106 (2002) 7882-7888

14. Foresman J.B., Keith T.A., Wiberg K.B., Snoonian J., Frisch M.J.: J. Phys. Chem. 100, (1996) 16098-16104 and references therein

15. Gaussian 03, Revision C.02, Frisch M.J., Trucks G.W., Schlegel H.B., Scuseria G.E., Robb M.A.,. Cheeseman J.R, Montgomery J.A., Jr., Vreven T., Kudin K.N., Burant J.C., Millam J.M., Iyengar S.S., Tomasi J., Barone V., Mennucci B., Cossi M., Scalmani G., Rega N., Petersson G.A., Nakatsuji H., Hada M., Ehara M., Toyota K., Fukuda R., Hasegawa J., Ishida M., Nakajima T., Honda Y., Kitao O., Nakai H., Klene M., Li X., Knox J.E., Hratchian H.P.,. Cross J.B, Bakken V., Adamo C., Jaramillo J., Gomperts R., Stratmann R.E., Yazyev O., Austin A.J., Cammi, R. Pomelli C., Ochterski J.W., Ayala P.Y., Morokuma K., Voth G.A., Salvador P., Dannenberg J.J., Zakrzewski V.G., Dapprich S., Daniels A.D., Strain M.C., Farkas O., Malick D.K., Rabuck A.D., Raghavachari K., Foresman J.B., Ortiz J.V., Cui Q., Baboul A.G., Clifford S., Cioslowski J., Stefanov B.B., Liu G., Liashenko A., Piskorz P., Komaromi I., Martin R.L., Fox D.J., Keith T., Al-Laham M.A., Peng C.Y., Nanayakkara A., Challacombe M., Gill P.M.W., Johnson B., Chen W., Wong M.W., Gonzalez C., and Pople J.A., Gaussian, Inc., Wallingford CT, 2004.

16. GaussView, Version 3.09, R. Dennington II, T. Keith, J. Millam, K. Eppinnett, W. L. Hovell, R. Gilliland, Semichem, Inc., Shawnee Mission, KS, 2003.

17. Shimanouchi T.: Tables of Molecular Vibrational Frequencies Consolidated Volume I. National Bureau of Standards (1972) 1-160 